


\title{
Lo gigantesco y la miniatura en Casa y Jardín de Ryue Nishizawa. La intimidad expuesta como materia arquitectónica The Gigantic and
} the Miniature in House and Garden by Ryue Nishizawa. Exposed Intimacy as Architectural Substance

\author{
Borja Ganzábal Cuena \\ Escuela Técnica Superior de Arquitectura, Universidad Politécnica de Madrid \\ Traducción Translation Borja Ganzábal Cuena
}

Palabras clave Keywords

Casa y Jardín, Ryue Nishizawa, alteración escalar, paisaje urbano, domesticidad, intimidad expuesta

House and Garden, Ryue Nishizawa, scalar alteration, urban landscape, domesticity, exposed intimacy

\section{Resumen}

A través de los conceptos de lo gigantesco y la miniatura —-derivados de la eliminación de la fachada tradicional - el presente articulo analiza la oposición escalar entre lo urbano y lo íntimo en Casa y Jardín, Tokio (2006-2011) de Ryue Nishizawa. El estudio del paisaje urbano y del programa, en relación con su exposición al ámbito público y la disposición de la vegetación revelan los sistemas arquitectónicos y de pensamiento que permiten que el edificio opere bajo la apariencia de haber eliminado su fachada; de la misma forma que una casa de muñecas, la intimidad expuesta de la vivienda se convierte en la expresión arquitectónica del proyecto y se complementa con una vegetación que sirve de atenuación y mediación entre el interior y el exterior. El artículo analiza la forma en la que la vivienda funciona enteramente como fachada — trasladando su ligereza hacia las partes más visibles - en lo que conforma una respuesta arquitectónica no convencional, para un lugar no menos convencional.

\section{Abstract}

By examining the concepts of the gigantic and the miniature derived from the elimination of the project's facade — the essay analyzes the scalar opposition between the urban and the intimate in House and Garden, Tokyo (2006-2011) by Ryue Nishizawa. The study of the urban landscape, the architectural program regarding its exposure to the public realm and the greenery reveal the architectural and though systems which allow the building to operate, apparently, without facade; as in a dollhouse, the house's exposed intimacy becomes its architectural expression, which is complemented by vegetation that mitigates and mediates between interior and exterior. The essay discusses the way in which the entire house functions as a facade - by concentrating its lightness qualities in its most visible parts - in what is a non-conventional architectural response, in a non-conventional site. 
¿Qué sucede cuando la vivienda prescinde de su propia fachada y la identidad íntima queda expuesta como materia arquitectónica? El artículo se centra en examinar los conceptos de lo gigantesco y la miniatura derivados de la eliminación de la fachada tradicional, así como en analizar los sistemas arquitectónicos que habilitan que la vivienda pueda operar sin fachada. (1) (Fig. 1)

Casa y Jardín es una casa y oficina para dos escritoras y editoras del ámbito del diseño y del arte. Cansadas de los largos desplazamientos desde los suburbios decidieron construir una vivienda en el barrio de Chūō, una de las zonas de mayor densidad de Tokio. (2) La vivienda atiende deliberadamente a un patrón habitacional de co-housing y co-working, en el cual ambas clientas - su relación personal sólo trasciende públicamente como "compañeras de negocio" - (3) comparten tanto la casa como el trabajo. De esta manera, la vivienda está concebida "como una casa y una oficina en la que dos compañeras de trabajo pueden vivir y trabajar juntas". (4)

El encargo del edificio - escrito por carta - recoge una reflexión acerca de la proliferación de sistemas alternativos de agrupación en vivienda. (5) En lugar de la agrupación por lazos familiares, las clientas especulan que el siglo xxi traerá la consolidación de otros modelos, tales como la agrupación de "amigos con ideas afines o conocidos". Así, las clientas entienden que la vivienda - que denominan 'futurista' - debe dejar de atender al "parentesco entre habitantes", para ofrecer "la posibilidad de cambiar la composición de los habitantes"; de esta forma, encargan al arquitecto una vivienda en la que las habitaciones individuales, correspondientes con el "número de personas que habitan la casa", sustituyan a los tradicionales dormitorios "de matrimonio o las habitaciones de los hijos". (6)

Más aún, con anterioridad a la construcción de la casa, ellas mismas se reconocen como usuarias de dichos patrones: "mis compañeros y yo somos actualmente este tipo de inquilino". (7) Asumen que estos patrones de agrupación conforman, por sí mismos, una nueva forma de habitar. Teniendo en cuenta que, de acuerdo con Fujioka, el régimen habitacional

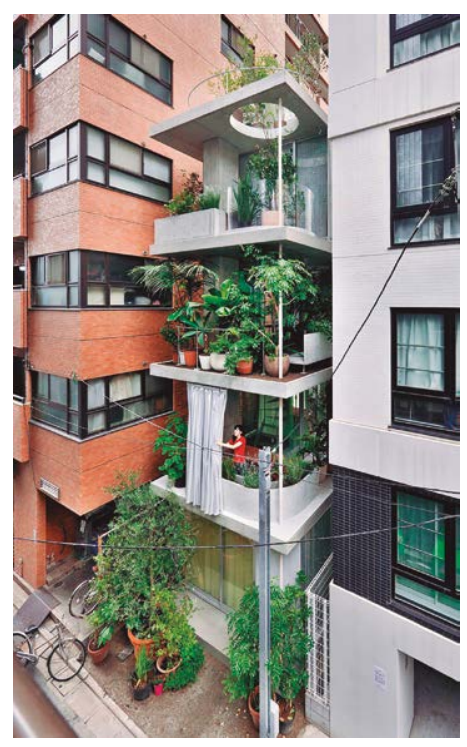

Fig. 1. Baan, Iwan: Garden and House, Tokio, Japan, 2011. ๑ Iwan Baan.

What are the consequences of eliminating a house's traditional facade and exposing the dweller's intimate identity as its architectural substance? The paper focuses on examining the concepts of the gigantic and the miniature derived from the elimination of the traditional facade, and analyzing the architectural systems that enable the house to operate without façade. (1) (Fig. 1)

House and Garden is a house and office for two writers and editors in the field of art and design. Tired of long commutes from the suburbs, they decided to build a house in the Chūō neighborhood, one of the densest areas of Tokyo. (2) The dwelling deliberately attends to a co-housing and co-working pattern, in which both clients - their personal relationship only transcends publicly as "business partners" - (3) share both house and work. Being so, the house is conceived "as house and office, where two colleagues can live and work together". (4)

The design request for the building included a concern regarding the proliferation of alternative housing patterns. (5) Rather than the usual patterns of family grouping, clients speculate that the 21 st Century would bring the consolidation of diverse models, such as "like-minded friends, or acquaintances". Thus, the clients understand that the dwelling — which they call 'futurist' - should not attend to "kinship among inhabitants", but rather offer the "possibility of changing the composition of its inhabitants". Therefore, they commission a house in which individual rooms, correspondent with the "number of people who inhabit the house" replace the traditional "marriage or children's rooms". (6) 
dominante en el desarrollo urbano de Tokio es la vivienda unipersonal - un tipo de vivienda que roza el cincuenta por ciento del mercado inmobiliario, mientras que sólo un 8,5 \% corresponde con la definición estándar de familia de acuerdo con el gobierno Japonés: padre, madre y dos hijos- (8) su especulación resulta certera.

Rodeada por torres de vivienda de más de treinta metros de altura - la flexibilización de las normativas en relación a las restricciones de altura y al ratio de superficie ocupada, tras la aprobación del Act on Special Measures Concerning Urban Regeneration de 2002, favoreció el desarrollo urbano de alta densidad en la zona-, (9) la vivienda se construye a partir del apilamiento de cuatro plantas libres de un perímetro rectangular de cuatro por ocho metros. Cada una de las plantas - excepto la planta baja - se compone de "una habitación y un jardín", donde la huella de la habitación es más pequeña que la huella del forjado, de forma que cada una de las habitaciones tiene una "forma y dimensiones acordes con su particular función". (10)

En la planta baja se albergan los servicios comunes requeridos por las clientas - comedor y cocina-, así como un jardín que se extiende por fuera de la huella del forjado hasta el límite con la calle. Por encima de ésta, cada una de las escritoras tiene una planta con un dormitorio individual, separadas entre sí mediante una planta intermedia donde se ubican los servicios higiénicos compartidos. Los dormitorios se complementan con una zona de trabajo integrada en el jardín, atendiendo a la demanda de las clientas de "poder concentrarse a solas en el trabajo de escribir". (11)

Las plantas se estructuran en base a tres franjas: una franja en contacto directo con la vía pública, donde se ubican las zonas de trabajo y de jardín; una franja intermedia, donde se ubica una escalera compensada, acompañada de un pequeño espacio de vestíbulo; y por último, una franja trasera que incluye los servicios - cocina, lavandería, baño, instalaciones y acceso a la cubierta- y los dormitorios. (Fig. 2) En palabras del arqui-

Moreover, prior to the house's construction, they recognize themselves as users of such new patterns. "I and my housemates are actually now this type of resident". (7) They assume that these patterns of grouping can be considered as a new form of living. Indeed, their speculation seems quite accurate, taking into account that according to Fujioka, the dominant housing regime of Tokyo's contemporary urban development is the single-person housing, a type of housing that represents almost $50 \%$ of the real estate market, while only $8.5 \%$ corresponds with the Japanese government's standard definition of family: father, mother and two children. (8)

Surrounded by residential towers more than thirty meters high —-flexible regulations concerning height restrictions and floor-space ratio approved in 2002 (Special Measures Concerning Urban Regeneration Act), favored a high-density urban development in the area-, (9) the house is built by stacking four rectangular, four by eight meter, open-floor plans. Each of the floors - except for the ground floor - consists of a "room and a garden", in which every room's area is smaller than the floor's perimeter, "allowing it to be shaped and given dimensions according to its particular functions". (10)

The ground floor locates the shared services required by the clients — dining and kitchen-, as well as a garden that extends itself outside the ceiling's perimeter, up to the limit with the public alley. Above the ground floor, each writer has her own floor with an individual bedroom and a workspace; an intermediate floor - where the shared hygienic services are located - separates the bedroom floors. The workspaces are integrated into the garden, and equipped with "a desk, a chair, and a bookcase", to allow the clients to "concentrate alone on the work of writing". (11) 


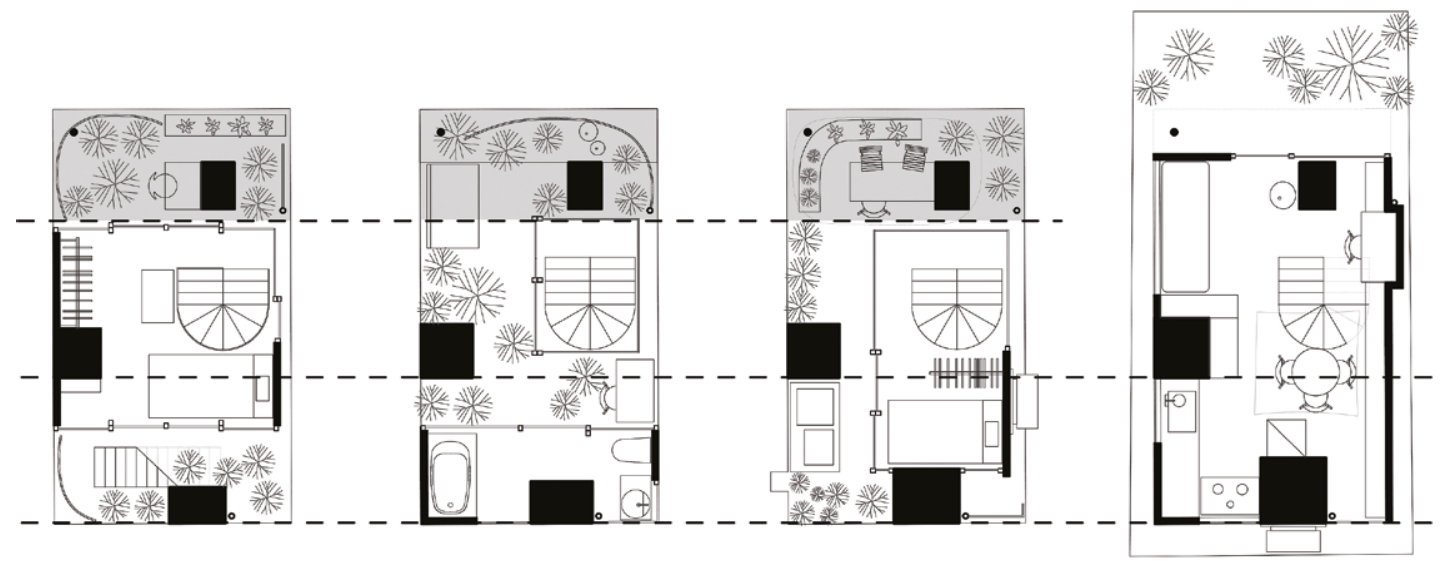

tecto, la razón por la que el proyecto prescinde de la fachada es sencilla y directa: "Teniendo en cuenta que el solar es muy pequeño, queríamos Fig. 2. Plantas de Casa y Jardín, 2015. evitar una reducción del área útil [...]. Nuestro concepto implicaba crear Dibujo del autor. un edificio sin muros". (12) Por lo tanto, la decisión responde a criterios funcionales y de eficacia, para maximizar la utilidad de uno los recursos más valiosos de Tokio: el suelo.

Lo gigantesco. La lógica arquitectónica que opone interior y exterior se disipa a través de la eliminación de la fachada. Sin embargo, las cualidades del interior y del exterior no desaparecen, sino que pasan a formar parte del mismo paisaje urbano a través de su confrontación escalar. Así, el interior se manifiesta en el exterior a través de la intimidad expuesta de quien habita la casa, mientras que el exterior se inserta en la vivienda para maximizar la percepción dimensional de la vivienda. De esta forma, la oposición tradicional entre interior y exterior se reformula, a través de una lógica escalar que Nishizawa asume como parte de su conjetura para el proyecto: "el paisaje creado por un edificio en su entorno urbano pue-

The layout is structured through three-striped scheme: a first stripe — directly facing the street - where work and garden areas are located; an intermediate stripe that contains a metallic staircase and a small lobby space; and a rear stripe, which includes services - kitchen, laundry, bathroom, facilities and roof-access - and bedrooms, enclosed with opaque walls in order to deal with privacy issues with the neighboring facades. (Fig. 2) According to the architect, the reason behind eliminating the facade is simple and direct: "since the site is very small, we wanted to avoid further reduction of the useable area [...]. Our concept involved creating a building without walls". (12) Therefore, the decision is a functional and efficient response in order to maximize the utility one of Tokyo's most valuable resources: land.

The Gigantic. The architectural logic that opposes interior and exterior dissipates when the facade is eliminated. However, neither the interior nor the exterior's qualities disappear completely, but rather become part of the same urban landscape through their scalar confrontation. Thus, the interior is manifested in the exterior by exposing the inhabitant's intimacy, while the exterior is inserted inside the house in order to maximize its perceived dimension.

Therefore, the traditional opposition between interior and exterior is reformulated through a scalar logic, which Nishizawa assumes as part of his conjecture for the design: "the particular landscape created by a building in its surrounding environment might serve to make the urban environment more attractive if it is constructed with an awareness of how its scale affects surrounding buildings and people". (13) 
de servir para hacerlo más atractivo, si se construye siendo consciente de cómo su escala afecta a los edificios que lo rodean y a la gente”. (13)

Precisamente, esa conciencia sobre la afectación de la escala en el entorno urbano queda representada de forma nítida en la maqueta urbana. En ella, el entorno aparece como un lugar abstracto, vasto, y fundamentalmente desproporcionado con la vivienda; la precisión y minuciosidad de la representación del mobiliario y la vegetación de la vivienda contrasta con la quietud y abstracción de una ciudad que desvanece toda vida en su interior. (Fig. 3) Esto evidencia la forma en la que, con el espacio doméstico expuesto, lo gigantesco y la miniatura aparecen como las categorías del paisaje urbano que genera; unas categorías relevantes para el análisis arquitectónico, en la medida en la que son capaces de expresar funciones y valores sociales: lo gigantesco, en relación a la naturaleza y a la vida pública y la miniatura, en relación a la formulación social del sujeto. (14)

Si la relación con lo gigantesco se articula desde la referencia al paisaje natural, (15) la metáfora de Nishizawa en relación al entorno no deja lugar a dudas: "el solar [...] está rodeado, en tres de sus lados, por edificios de más de treinta metros de altura que lo convierten en un pequeño valle oscuro rodeado por una construcción montañosa”. (16) En esta descripción -ampliamente publicada - ninguno de los términos que el arquitecto asocia a elementos naturales corresponden con la naturaleza propia del proyecto, ni con ningún paisaje natural. Más bien, tanto el 'valle oscuro' como la 'construcción montañosa' se refieren a la materia arquitectónica del entorno. En el paisaje urbano que genera la vivienda, la categoría de lo gigantesco ya no se corresponde con las fuerzas naturales - fascinantes, terroríficas - sino que ahora, son las fuerzas de la ciudad las verdaderamente aterradoras.

Coherentemente con este planteamiento, la naturaleza propia del proyecto - la vegetación - no funciona albergando o conteniendo la arquitectura. Más bien, se sitúa 'dentro' de ella, en la misma categoría en la que se sitúan tanto las personas como el mobiliario: esto es, la miniatura; una categoría
Fig. 3. Legendre, Michel: Maqueta de Casa y Jardín, 2008. Michel Legendre $\odot$ Canadian Centre for Architecture.

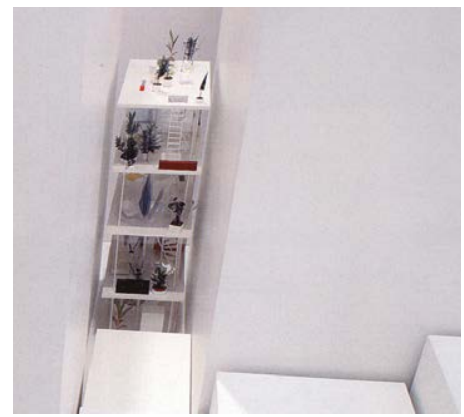

Precisely, the awareness of scalar effect in the urban environment is clearly represented in the urban model, where the surrounding buildings appear as an abstract, vast, and fundamentally disproportionate construction when compared to the house. Furthermore, the precision and meticulousness of the representation of the house's furniture and vegetation, highly contrasts with the city's stillness and abstraction, as if all life had been vanished from it. (Fig. 3) This renders evident the way in which, by exposing domestic space, the gigantic and the miniature appear as the categories of the urban landscape it generates. These categories are relevant for architectural analysis to the extent that they are capable of expressing social functions and values: the gigantic, in relation to nature and public life, and the miniature, in relation to the social formulation of the subject. (14)

Therefore, if the relationship with the gigantic is articulated by referencing the natural landscape, (15) Nishizawa's metaphor regarding the surrounding conditions leaves no room for doubt: "the [...] site is encompassed on three sides by buildings more than thirty meters high, making it much like a small dark valley surrounded by a mountainous construction". (16) In this widely published description, none of the terms associated with natural elements corresponds to the nature inside the project itself, or any other natural landscape. Rather, both 'dark valley' and 'mountainous construction' refer to the architectural matter of the surrounding buildings. In the urban landscape generated by the house, the gigantic no longer corresponds to natural forces - fascinating, terrifying-; instead, it is the city's forces that are truly terrifying. 
delicada, ligera y desprovista de fuerza. (Fig. 4) Si tradicionalmente la construcción cultural de lo natural se había basado en la oposición directa entre artificio y naturaleza - o campo y ciudad-, lo que propone Nishizawa es un paisaje urbano en el que lo natural deja de formar parte de lo gigantesco para pasar a formar parte de la miniatura: la naturaleza pierde la capacidad de ser contenedora y comparte espacio y escala con el ser humano. Este espacio compartido - la miniatura - exhibe su intimidad y proporciona cobijo frente a la alienante ciudad genérica, lo gigantesco.

La miniatura El proyecto de Nishizawa exhibe su intimidad a través de un funcionamiento que remite a aquel, mediante el cual opera una casa de muñecas: eliminación de la fachada frontal para desplegar ante la vista ajena una vida secreta que permanecía oculta y representativa de un estatus social privilegiado. (17) De forma que si la aspiración de Nishizawa es la de crear "paisajes atractivos que reflejen los valores del tiempo presente", (18) la materia de esos valores - y de la arquitectura- es el despliegue simultáneo de la intimidad. (19) (Fig. 5) Ciertamente, un mecanismo como el de Nishizawa puede inducir a pensar en una situación equivalente a la arquitectura panóptica de Bentham: una cárcel transparente. Sin embargo, hay una diferencia fundamental que las aleja: si el panóptico optimizaba la vigilancia situando a los observados en el perímetro -máximos sujetos observados, mínimos observadores - la vivienda de Nishizawa plantea la situación inversa: mínimos sujetos observados, máximos observadores. Sucede entonces que la exposición de la intimidad no genera una arquitectura carcelaria, sino que construye el escaparate de un determinado 'estilo de vida' o lifestyle. (20)

Precisamente, el encargo de las clientas plantea la posibilidad de aplicar sobre la vivienda determinaciones específicas del estilo de vida LOHAS: (21) “¿es posible aplicar esta idea en la vivienda?”. (22) Según las clientas, dicho estilo de vida implica adoptar "una vida orgánica y lenta, sin ir en contra del ritmo de la naturaleza"; precisamente, el ritmo de la naturaleza y sus diferentes condiciones estacionales pasan a formar parte activa de la vida de las clientas, a través de la necesidad de cuidado permanente — una
Fig. 4 Nishizawa, Ryue: Office of Ryue Nishizawa: Garden and House, 2011. @ Museum of Modern Art of New York

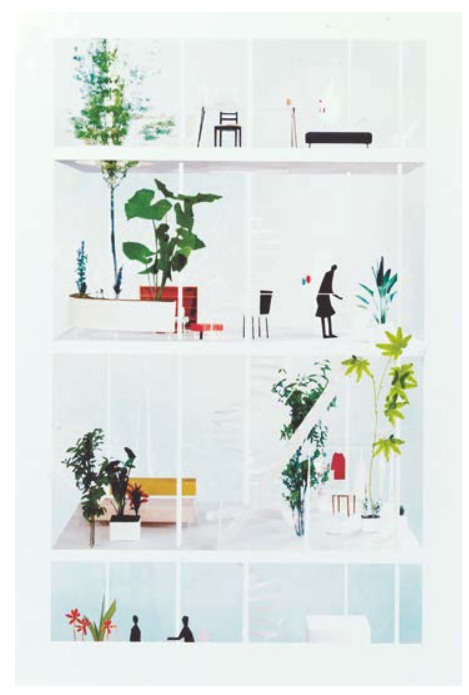

Consistent with this approach, the project's nature - vegetation - does not have the ability to shelter or contain architecture. Rather, it is held 'within' architecture, in the same category in which both people and furniture are situated: i.e., the miniature; a delicate, light, and devoid of strength category. (Fig. 4) If the concept of the natural has been traditionally and culturally built upon a direct confrontation between artifice and nature - or country and city-, Nishizawa proposes an urban landscape in which the natural ceases being part of the gigantic, to become part of the miniature: nature has lost its ability to contain, and now, it shares space and scale with the human being. This shared space between the natural and the individual — the miniature-, exhibits its intimacy and provides shelter from the alienating generic city, the gigantic.

The Miniature. Nishizawa's project exhibits its intimacy by operating like a dollhouse, eliminating its front facade to display a secret life that was hidden, and that is representative of a privileged social status. (17) Thus, if the architect's aspiration is to create "attractive landscapes that reflect the values of the present time", (18) the substance of those values - and of architecture - is the simultaneous unfolding of intimacy. (19) (Fig. 5) Nishizawa's mechanism can certainly lead to think of an equivalent situation to that of Bentham's panoptic architecture: a transparent prison. However, there is a fundamental difference among them: if the panoptic optimized surveillance by situating the observed in the perimeter - maximum observed subjects, minimum observers - Nishizawa's house implies the inverse situation: minimum observed subjects, maximum observers. Therefore, its exposed intimacy generates a showcase of a certain lifestyle, (20) instead of a prison. 
performance perpetua que garantiza su viabilidad- (23) y evidencian la inserción activa del "culto a la naturaleza en el ámbito cotidiano". (24) Pero, ¿qué es exactamente lo que queda expuesto en Casa y Jardín? A diferencia de las maquetas de estudio, en las que absolutamente todo queda expuesto al escrutinio permanente, la obra construida es más sofisticada en su articulación de lo que muestra y lo que no.

Según el plano que se consulte, las actividades de la planta baja quedan definidas mediante un genérico space 1, (25) o unos, algo más concisos, living, dinning y kitchen. (26) La disposición espacial de estas actividades aprovecha la colocación de los masivos pilares interiores para construir una secuencia alveolar, en la que tanto la sala como el comedor reafirman su espacialidad propia mediante el uso de alfombras sobre el pavimento de hormigón pulido, mientras que la encimera metálica de la cocina en esquina se separa del suelo mediante unas esbeltas patas metálicas. Así mismo, el pilar interior de la fachada sur se reviste con una estantería de madera, mientras que toda la cara interior de la fachada norte es una estantería longitudinal que queda interrumpida por un pequeño escritorio. Inicialmente ubicado en un sótano no construido -denominado archive - (27) este espacio de almacenamiento bibliográfico compartido (28) está pensado para ser utilizado por el ayudante de una de las escritoras.

Sin embargo, todas las actividades de la planta baja y toda su abundancia de objetos cotidianos - sartenes colgadas, libros, revistas, cestos, frutas, teteras, manoplas, luminarias, y velas- no se exponen abiertamente como parte de la miniatura. (Fig. 6) La planta baja - que abarca la totalidad de la huella del forjado, a excepción de un pequeño porche de acceso-cuenta con cerca de un $65 \%$ de su perímetro total cerrado mediante una fachada opaca, quedando la fachada norte completamente cerrada. Los paños de vidrio que se abren a la vía pública — oeste - se complementan con una serie de cortinas translúcidas en su interior, mientras que la parte trasera -fachada este- entrega contra la planta baja del edificio colindante. De esta manera, Nishizawa construye una planta baja opaca y cerrada en la
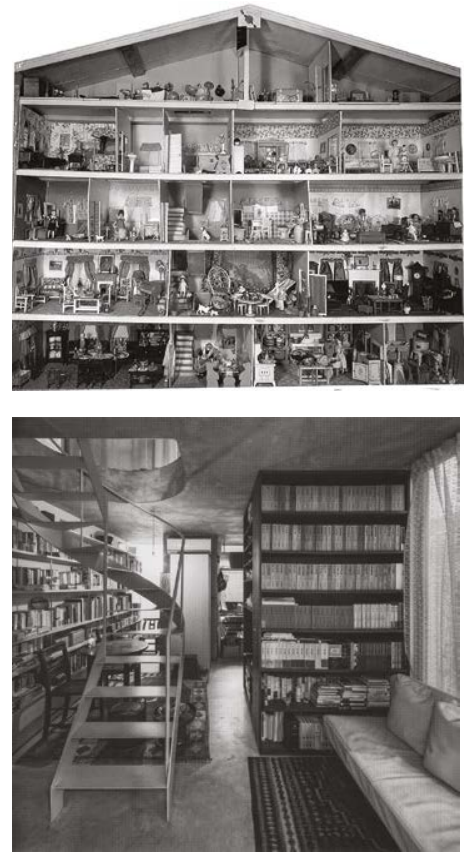

Fig. 5. Bradford, Faith: Dollhouse at Gadsby's Tavern, 1932. $\odot$ National Museum of American History.

Fig. 6. Tanaka, Katsumasa; Mizoguchi, Yuta. Space 1: View from Entrance, 2013. Fuente: $G A$ Houses, n. 131, p. 31, Tokio.

Furthermore, the client's commission raised the possibility of applying to the house specific determinations of the LOHAS lifestyle: (21) "is it possible to apply this idea in the home?" (22) According to the clients, this lifestyle implies adopting "an organic and slow life, without going against the rhythm of nature"; precisely, the rhythm of nature and its different seasonal conditions become an active part of the clients' lives through the demand of permanent care - a perpetual performance that guarantees its viability-, (23) and clearly show an active insertion of a "nature worship into everyday life". (24) But, what exactly is exposed in Home and Garden? Unlike the studio models - where absolutely everything is exposed to permanent scrutiny - the built work is much more sophisticated in its articulation of what it shows and what it does not.

Depending on the consulted plan, its activities on the ground floor are defined by a generic Space 1, (25) or a more concise living, dining, and kitchen. (26) The spatial arrangement of these activities uses the placement of the massive interior columns to build an alveolar sequence, in which both living and dining rooms reaffirm their own spatiality by using carpets over the polished concrete floor, while the cornered metal kitchen separates itself from the floor through slender metal legs. Likewise, the interior column of the southern facade is covered with a wooden shelf, while the entire interior surface of the north facade is a longitudinal shelf interrupted only by a small desk. Initially located in an unbuilt basement — named archive in initial plans_, (27) this shared bibliographical storage space, (28) is though to be used by one of the writer's assistants. 
que las funciones típicamente públicas y abiertas de la vivienda moderna - sala, comedor y cocina; zona de día - se convierten en el ámbito más íntimo e introvertido de la casa.

Por el contrario, lo más expuesto en Casa y Jardín es lo que sucede en las plantas superiores, en las que cada una de las escritoras cuenta con una planta con dormitorio individual y una zona de trabajo en el jardín, bedroom y office. (29) El dormitorio de la primera planta queda reducido a la longitud mínima de una cama, permitiendo el acceso exterior a una zona de lavandería. El dormitorio se completa mediante un colgador metálico longitudinal que sirve de armario, y que - junto con una cortinacompartimenta el espacio y separa la cama de la zona de la escalera. La zona de trabajo está pensada para "recibir visitas" y para, "en un futuro, [...] exponer los productos [editoriales] acabados". (30) Cuenta, para ello, con una "gran mesa de reuniones" con espacio para hasta cinco personas sentadas y - ubicada fuera de la zona climatizada de la vivienda- puede llegar a separarse tanto de la calle como de la vivienda, mediante una cortina opaca plateada. En cambio, el dormitorio de la tercera planta es un espacio enteramente privado de las visitas externas. Aquí, la escalera también forma parte del espacio del dormitorio y las cortinas, en lugar de funcionar como separadores internos de la vivienda, se ubican en las zonas transparentes del perímetro para controlar la relación exterior. La mesa de trabajo exterior de la tercera planta, más reducida que la de la primera planta, solo tiene espacio para una silla.

Ambas plantas de dormitorio evidencian una diferencia de privacidad: la tercera planta, atiende a la definición inicial de las clientas de una "habitación individual", (31) mientras que el dormitorio de la primera planta forma parte de lo que las clientas denominan 'zona gris': "significa que el espacio tiene dos aspectos: privado y público. Su uso se supone como ampliación del espacio de trabajo". (32) Sin embargo, ambas zonas de trabajo comparten ubicación en una primera franja - en contacto directo con la vía pública- que tiene un rango que oscila entre los 2 y los 2,3 metros.

However, all of the ground floor's activities and all its abundance of everyday objects - the hanging pans, books, magazines, baskets, fruit, teapots, mittens, luminaries, and candles - are not openly exposed as part of the miniature. (Fig. 6) $65 \%$ of the ground floor - which encompasses the entire ceiling's footprint, with the exception of a small access porchhas an opaque perimeter, having the entire north facade completely closed. Moreover, the transparent windows facing the public street —-west facade-, are complemented with a series of translucent interior curtains, while the rear facade —east facade - is placed directly against the adjoining building's facade. Therefore, Nishizawa builds an opaque and closed ground floor, in which the typically open and public functions of modernist dwellings - living, dining, kitchen; day-zone- become the most intimate and introverted part of the house.

Conversely, the most exposed part of Home and Garden is what happens in the upper floors, where each of the writers has an individual floor plan with a single bedroom and a workspace in the garden. (29) The bedroom on the first floor is reduced to the minimum length of a bed, which allows for an outside access to a laundry area. The bedroom is completed with a longitudinal metal hanger that is used as a closet, and which —along with a curtain-, divides the space and separates the bedroom area from the staircase. The workspace is designed in order to "receive visitors" and "in the future, [...] exhibit finished [editorial] products". (30) Being so, it is equipped with a "large meeting table" with space for up to five people, and - located outside the heated area of the house - it can achieve intimacy, from the street and from the house, by rolling a silver curtain. The bedroom on the third floor, however, is a space entirely deprived from external visitors. Here, the staircase is part of the bedroom space, and the curtains, instead of 
[ver Fig. 2] Si tomamos como referencia las alturas libres (2,75 metros) y la anchura de la vía pública (4 metros aproximadamente), no existe la posibilidad de contacto visual entre la vía pública y las zonas más íntimas de la vivienda. Como refuerzo para esta situación tectónica, el arquitecto dispone de una serie de barandillas y protecciones distintas en cada planta: en la primera, una cortina plateada y una jardinera de hormigón in-situ; en la segunda, una barandilla de tubo metálico y una barrera de macetas; en la tercera, de nuevo, una jardinera de hormigón y una barandilla acrílica transparente que coincide con la perforación circular de la cubierta, y que permite ver el cielo desde la calle y a través del edificio. (Fig. 7)

Sin embargo, el elemento principal de la fachada es la vegetación. No en vano, y previo a la definición del programa, el proyecto busca estrategias para la adecuación escalar de lo natural a través de una serie de maquetas: desde su completa ausencia, su abstracción orgánica en forma construida, pasando por una vegetación de gran porte de entre dos y tres pisos de altura. (Fig. 8) Finalmente, el proyecto opta por la disposición - en todo el ancho de fachada- de una mayor cantidad de unidades de menor tamaño, que atienden a la altura libre de la planta y a la escala del cuerpo, y que se complementan mediante un arbolado de mayor porte que nace del jardín de la planta baja. De esta forma, el control con respecto a los edificios colindantes se efectúa a través de la abundancia, la proximidad y el tamaño de la vegetación. En las plantas primera y tercera, mediante una vegetación de tallo fino, espigado -lavanda, romero, hemerocallis - de desarrollo vertical y enraizado en macetas que funcionan como antepechos; en la planta segunda, mediante una vegetación exuberante, tropical, de hoja ancha y perenne - helechos, musas, monsteras-, que a diferencia de la anterior, tiende a desarrollarse de forma espacial, protegiéndola especialmente de la permeabilidad exterior.

La vegetación, deudora de una tradición de jardinería urbana en Tokio, adquiere la condición de objeto a través de la manera en la que se contiene. Así, en lugar de proponer un sistema integrado; eliminando la necesidad
Fig. 7. Sagarminaga Ayastuy, Mikel, 2017.

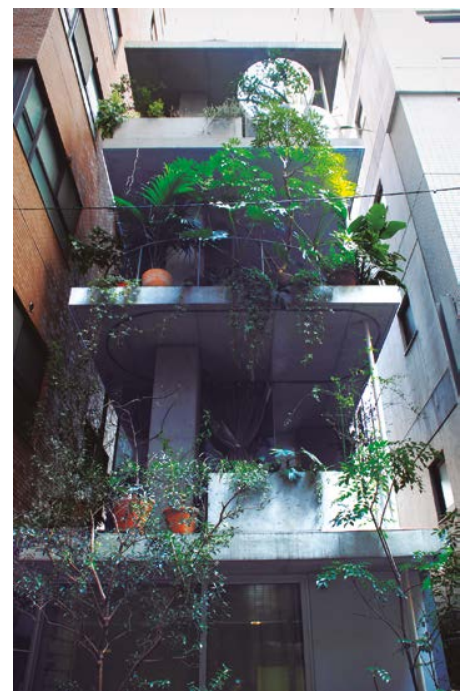

working as interior divisions, are located — to control the relationship with the exterior- in the transparent areas of the perimeter. The external workspace, much smaller than the one on the first floor, has space for only one chair.

A difference in their internal privacy is evident in the bedrooms: the third floor's bedroom meets the client's initial definition of a "single room", (31) while the first floor's bedroom, is part of what the clients call 'gray area', which "means a space with two aspects: private and public. Its use is supposed to be an extension of the workspace". (32) However, both workspaces share a location in a first stripe that has direct contact with the street, and that has a dimensional range between 2 and 2.3 meters. [see Fig. 2] Taking into account the ceiling's heights ( 2.75 meters) and the street width (4 meters approximately), there is no possibility of visual contact between the pedestrian and the most intimate areas of the house. As a reinforcement to this tectonic disposition, the architect places a series of different protections and railings on each floor; on the first floor, a silver curtain and a built-in concrete planter; on the second floor, a metal railing and a barrier of planted pots; on the third floor, again, a concrete planter, and a transparent acrylic protection, that coincides with the circular opening on the roof, so allowing the pedestrian to see the sky from the street, and through the building. (Fig. 7)

However, the facade's most important element is the vegetation. Even prior to the definition of an architectural program, the different models reveal a search for an adequate scalar strategy for the natural elements: from a complete absence, to a formal organic abstraction, or a bigger vegetation - two and three stories high. (Fig. 8) Finally, the architect chose the provision of a larger number of smaller sized units — encompassing the complete width of the facade - that attend to the 


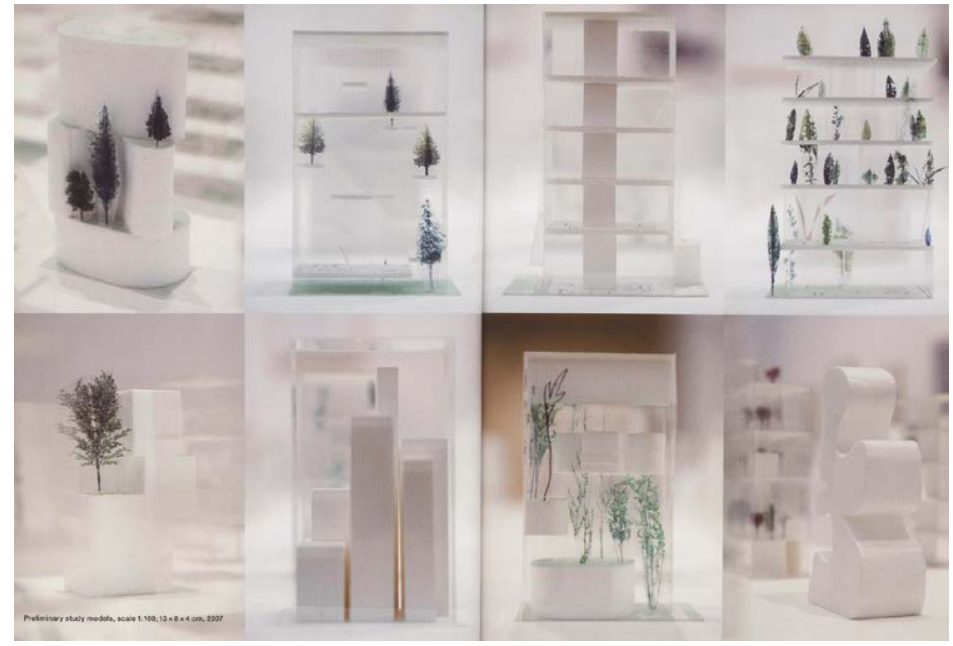

de un tiempo de crecimiento in-situ, Nishizawa dispone la vegetación en macetas que la separan de la arquitectura, la colocan en la categoría escalar del mobiliario y las personas, y requieren de mantenimiento constante. Las cualidades de la vegetación, así como la de los pavimentos - tierra prensada u hormigón pulido- convierten la fachada vegetal en mediadora de una arquitectura altamente inmersiva, que además es habitable. Junto con la vegetación, las zonas de trabajo se ubican en clara relación con la calle; de esta forma, la vivienda expande la esfera doméstica e introduce en ella paisaje, urbanidad y trabajo. (Fig. 9) A diferencia de las maquetas de estudio más conocidas, que presentan una vivienda con un comportamiento estructural ligero y una vegetación isótropa, la obra se construye con muchísima más precisión: la vegetación —concentrada especialmente en la primera franja - varía de especies y de características en función del programa que alberga, mientras que los elementos estructurales aumentan su tamaño a medida que se alejan de la calle. Los forjados, que vuelan
Fig. 8. Legendre, Michel: Maquetas de Casa y Jardín, 2008. Michel Legendre $\odot$ Canadian Centre for Architecture.

ceiling's height and the body's scale. This potted vegetation is complemented with larger vegetation, planted in the garden on the ground floor. By doing so, the privacy regarding the neighboring buildings is controlled through the abundance, proximity, and size of the plants. On the first and third floors, there is a fine-stemmed, slim vegetation - lavender, rosemary, hemerocallis -, which develops vertically and is planted inside the built-in concrete planters; on the second floor, there is an exuberant, tropical, broad-leaved, perennial vegetation - ferns, musa, monstera - which, unlike the previous, tend to develop spatially, and therefore, offer the shared bathroom a special protection from outer permeability.

The disposition of the greenery, which comes from a tradition of urban-gardening in Tokyo, acquires the status of object by the way it is contained. Thus, instead of proposing an integrated system; therefore, eliminating the need for an in-situ growth-time, Nishizawa arranges the greenery in diverse pots, which separates them from the architecture, locates them in the scalar category of both furniture and people, and requires constant maintenance. The vegetation's qualities, as well as the pavement's qualities - either pressed earth, or polished concrete - turn the green facade into a mediator of a highly immersive and habitable architecture. Along with the g reen spaces, the workspaces are clearly related to the street; therefore, the house expands the scope of its domestic sphere by introducing landscape, urbanity, and workspace in the dwelling. (Fig. 9) Unlike the best-known studio models, which offer a structurally light behavior and isotropic vegetation, the built work is much more precise: the vegetation — concentrated especially on the first strip — varies in species and characteristics depending on the program it deals with, while the structural elements increase in size as they move away from the street. The concrete slabs, which strategically extend to impede the view from the street, are perforated in the roof, in order to allow a sight of the sky through the building. 
estratégicamente para impedir la visión desde la vía pública, sin embargo, se agujerean en la cubierta para permitir ver el cielo.

Conclusión. A pesar de la diferencia entre la vegetación de la Casa de Muñecas - plana, figurativa en el papel pintado y las cenefas con motivos florales - y Casa y Jardín - profunda, literal y activamente presente en el espacio-, su comportamiento es equivalente como ornamentación del espacio arquitectónico: es la expresión pública de ese universo interior desplegado, al tiempo que decoración interior y atenuante de cualquier cotidianidad prosaica.

Macizar la planta baja y encerrar las funciones tradicionalmente públicas de la vivienda, para abrir las plantas superiores y exponer las zonas de trabajo - dormitorios y baños- supone una inversión clara del paradigma de vivienda sobre pilotis de la modernidad, así como el de la correlación entre privado y público de la dualidad moderna de espacios servidores y servidos. Más aún, Nishizawa construye una psicología inversa: si el conflicto de la privacidad está entre el espacio privado, la mirada pública y la calle, el arquitecto desvía la atención hacia unas plantas superiores, donde la exuberante vegetación sacia al voyeur con la ilusión de una intimidad ajena.

En una estrategia que, nada tiene que ver con el regreso a una naturaleza contenedora, la vegetación es el elemento que se encarga de mediar en la oposición escalar entre lo urbano y lo íntimo, así como en la separación del entorno y del programa. (33) Precisamente, a través de su condición de objeto, la vegetación consigue que la vivienda aparente que opera sin fachada. Sin embargo, el edificio no opera sin fachada: la organización de las actividades en planta, la magnitud de los elementos estructurales, la colocación y elección de la vegetación y el traslado de su discurso de ligereza hacia las partes más visibles, hacen que el edificio se construya 'enteramente' como una fachada. De esta forma, el arquitecto da una respuesta no convencional a la petición expresa de las clientas de tomar medidas para que "no se pueda atisbar el interior del edificio". (34)
Fig. 9. Secuencia de fotografías. Montaje del autor.

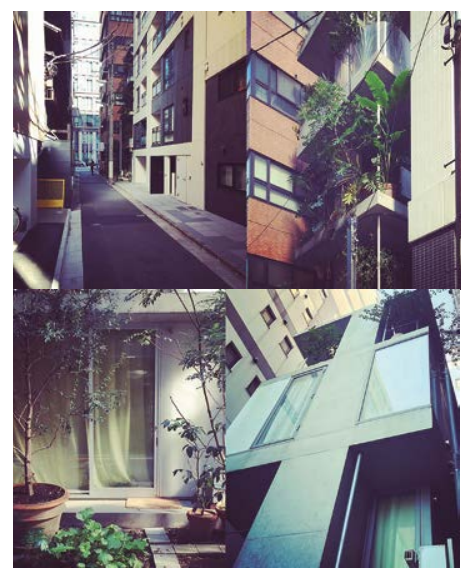

Conclusion Despite the difference between the dollhouse's vegetation - superficial; figurative on the wallpaper with floral motifs — and that of House and Garden — deep; literally and actively present—, their behavior is equivalent in terms of ornamenting architectural space: it is the public expression of an unfolded interior universe, as well as its interior decoration, and mitigation of any prosaic everyday life activity.

Enclosing the ground floor and the traditionally public functions of modernist dwelling — living, dining —, in order to open the upper floors and expose the workspace, bedrooms and bathrooms, is a clear inversion of the modernist paradigm of house over pilotis. Furthermore, it alters the correlation between private and public of the modernist duality of served and service spaces. What Nishizawa does is a complete reverse psychology: if the privacy conflict is between private space, the public eye and the street, the architect diverts attention to the upper floors, where the exuberant vegetation satisfies the voyeur with the illusion of an exposed privacy.

In a strategy that has nothing to do with returning to a gigantic nature, greenery is responsible mediating the scalar opposition of the urban and the intimate, as well as the separation of environment and the program. (33) Precisely, through the greenery's condition of object, the house manages to appear as if it operates without facade. However, the building does not operate without a facade: the layout of its activities, the magnitude of its structural elements, the placement and choice of the greenery, and the reallocation of its lightness discourse towards its most visible parts, make the 'entire' building work as a facade. In this way, the architect gives an unconventional response to the client's request of making sure "you can not peek inside the building". (34) 


\section{NOTAS}

1. Casa y Jardín, Ryue Nishizawa, Tokio, 2006-2011.

2. DIMMER, C. 'Perpetual Performance (Living in Ryue Nishizawa's House and Garden)', Architectural Review Asia Pacific. The Residential Issue, n. 127. Octubre, 2012. pp. 60-65.

3. DIMMER, C. Ibidem. 2012.

4. NISHIZAWA, R.; TAKAHASHI, I. Opus cit. 2009. p. 26.

5. Las tres hojas del manuscrito original del encargo de la vivienda aparecen reproducidas en idioma japonés en NISHIZAWA, R.; TAKAHASHI, I. Opus cit. 2009. p. 25. Traducción íntegra de dichos manuscritos, por primera vez del japonés al castellano, por parte del autor.

6. NISHIZAWA, R.; TAKAHASHI, I. Opus cit. 2009. p. 25. Traducción íntegra de los manuscritos, por primera vez del japonés al castellano, por el autor. 7. NISHIZAWA, R.; TAKAHASHI, I. Opus cit., 2009. p. 25.

8. FUJIOKA, Hiroyasu. AA.VV. 'A History of the Individual House in Modern Japan', The Japanese House: Architecture and Life After 1945. Lodres, Roma y Venecia: Barbican Centre, MAXXI, Marsilio Editori, 2017. p. 14.

9. KITAYAMA, Koh. 'Changes in Urban Areas of Toyko at the Beginning of the 21st Century', en KITAYAMA, K.; TSUKAMOTO, Y.; NISHIZAWA, R. Toyko Metabolizing. Tokio: TOTO Publishing, 2010. pp. 15-27.

10. BORASI, G.; NISHIZAWA, R.; TAYLOR, S.J. Some Ideas on Living in London and Tokyo. Québec: Canadian Centre for Architecture, 2008. p. 14. 11. NISHIZAWA, R.; TAKAHASHI, I. Opus cit., 2009. p. 25. Traducción íntegra de los manuscritos, por primera vez del japonés al castellano, por el autor. 12. BORASI, G.; NISHIZAWA, R.; TAYLOR, S.J. Opus cit., 2008. p. 14.

13. NISHIZAWA, R., 'Buildings that Evoke Contemporary Values', en BORASI, G.; NISHIZAWA, R.; TAYLOR, S.J. Opus cit. 2008. pp.10-13.

14. STEWART, S. On Longing: Narratives of the Miniature, the Gigantic, the Souvenir, the Collection. Baltimore: John Hopkins University Press, 1984. p. 95. 15. STEWART, S. Opus cit. 1984. p. 71.

16. BORASI, G.; NISHIZAWA, R.; TAYLOR, S.J. Opus cit. 2008. p. 14.

17. STEWART, S. Opus cit. 1984. pp.61-62.

18. NISHIZAWA, R. 'Buildings that Evoke Contemporary Values', en BORASI, G.; NISHIZAWA, R.; TAYLOR, S.J. Opus cit. 2008. pp. 10-13.

19. STEWART, S. Opus cit. 1984. pp. 66-67.

20. FEATHERSTONE, M. Consumer Culture and Postmodernism. Londres: SAGE Publications, 2007.p. 81.

21. LOHAS es el acrónimo de Lifestyles of Health and Sustainability. Descrito por primera vez en RAY, P.H.; ANDERSON, S.R. The Cultural Creatives: How
NOTES

1. House and Garden, Ryue Nishizawa, Tokyo, 2006-2011.

2. DIMMER, C. 'Perpetual Performance (Living in Ryue Nishizawa's

House and Garden)', Architectural Review Asia Pacific. The Residential

Issue, n. 127, October 2012. pp.60-65.

3. DIMMER, C. Opus cit.2012.

4. NISHIZAWA, R., TAKAHASHI, I. Opus cit. 2009. p. 26.

5. Three pages of the original design request appear in Japanese language in NISHIZAWA, R., TAKAHASHI, I. Opus cit. 2009. p. 25. Translated by the author.

6. NISHIZAWA, R., TAKAHASHI, I. Opus cit. 2009. p. 25. Translated by the author.

7. NISHIZAWA, R.; TAKAHASHI, I. Opus cit. 2009. p. 25.

8. FUJIOKA, Hiroyasu, AA.VV. 'A History of the Individual House in

Modern Japan', The Japanese House: Architecture and Life After 1945.

London, Rome and Venice: Barbican Centre, MAXXI, Marsilio Editori, 2017.p. 14.

9. KITAYAMA, Koh. 'Changes in Urban Areas of Toyko at the Beginning of the 21st Century', in KITAYAMA, K., TSUKAMOTO, Y., NISHIZAWA,

R. Toyko Metabolizing, TOTO Publishing, Tokyo, 2010. pp. 15-27.

10. BORASI, G.; NISHIZAWA, R.; TAYLOR, S.J. Some Ideas on Living

in London and Tokyo. Quebec: Canadian Centre for Architecture, 2008. p. 14.

11. NISHIZAWA, R.; TAKAHASHI, I. Opus cit. 2009. p. 25. Translated by the author.

12. BORASI, G.; NISHIZAWA, R., TAYLOR, S.J. Opus cit. 2008. p. 14. 13. NISHIZAWA, R., "Buildings that Evoke Contemporary Values", in BORASI, G.; NISHIZAWA, R.; TAYLOR, S.J. Opus cit.2008. pp. 10-13. 14. STEWART, S. On Longing: Narratives of the Miniature, the Gigantic, the Souvenir, the Collection. Baltimore: John Hopkins University Press, 1984. p. 95.

15. STEWART, S. Opus cit. 1984. p. 71.

16. BORASI, G.; NISHIZAWA, R.; TAYLOR, S.J. Opus cit. 2008. p.14. 17. STEWART, S. Opus cit.1984. pp. 61-62.

18. NISHIZAWA, R., 'Buildings that Evoke Contemporary Values', in BORASI, G.; NISHIZAWA, R.; TAYLOR, S.J. Opus cit. 2008. pp. 10-13. 19. STEWART, S. Opus cit.1984. pp. 66-67.

20. FEATHERSTONE, M. Consumer Culture and Postmodernism. London: SAGE Publications, 2007. p. 81.

\section{REFERENCIAS}

AA.VV. The Japanese House: Architecture and Life After 1945, Barbican Centre, Londres, MAXXI, Roma, Marsilio Editori, Venecia, 2017.

AA.VV. The SANAA Studios 2006-2008: Learning from Japan. Single Story Urbanism, Lars Müller Publishers, 2010.

BORASI, G., NISHIZAWA, R.; TAYLOR, S.J. Some Ideas on Living in London and Tokyo. Canadian Centre for Architecture, Québec, 2008.

DIMMER, C. 'Perpetual Performance (Living in Ryue Nishizawa's House and Garden)', Architectural Review Asia Pacific, The Residential Issue, n. 127, octubre, 2012.

NISHIZAWA, R.; TAKAHASHI, I. Nishizawa Ryūe / Nishizawa Ryūe Kenchiku Sekkei Jimusho Sutadi-Shü, Studies by the Office of Ryue Nishizawa, INAX Shuppan, Tokio, 2009.

SEJIMA, K.; FUTAGAWA, Y.; NISHIZAWA, R. GA Architect: Kazuyo Sejima, Ryue Nishizawa 2006-2011. Tokyo ADA Edita, Tokio, 2011.

STEWART, S. On Longing: Narratives of the Miniature, the Gigantic, the Souvenir, the Collection. John Hopkins University Press, Baltimore, 1984. ZANCAN, R. 'Tokyo's Vertical Thresholds', DOMUS, n. 953. p. 33, Casa Ed. Domus, Milán, Diciembre, 2011.

\section{REFERENCES}

AA.VV. The Japanese House: Architecture and Life After 1945, Barbican Centre, Londres, MAXXI, Roma, Marsilio Editori, Venice, 2017.

AA.VV. The SANAA Studios 2006-2008: Learning from Japan. Single Story Urbanism, Lars Müller Publishers, 2010.

BORASI, G., NISHIZAWA, R.; TAYLOR, S.J. Some Ideas on Living in London and Tokyo. Canadian Centre for Architecture, Quebec, 2008.

DIMMER, C. 'Perpetual Performance (Living in Ryue Nishizawa's House and Garden)', Architectural Review Asia Pacific, The Residential Issue, n. 127, October, 2012.

NISHIZAWA, R.; TAKAHASHI, I. Nishizawa Ryūe / Nishizawa Ryūe Kenchiku Sekkei Jimusho Sutadi-Shū, Studies by the Office of Ryue Nishizawa, INAX Shuppan, Tokyo, 2009.

SEJIMA, K.; FUTAGAWA, Y.; NISHIZAWA, R. GA Architect: Kazuyo Sejima, Ryue Nishizawa 2006-2011. Tokyo ADA Edita, Tokyo, 2011.

STEWART, S. On Longing: Narratives of the Miniature, the Gigantic, the Souvenir, the Collection. John Hopkins University Press, Baltimore, 1984. ZANCAN, R. 'Tokyo's Vertical Thresholds', DOMUS, n.953. p. 33, Casa Ed. Domus, Milan, December, 2011. 
50 Million People Are Changing the World. EE.UU.: Harmony Books, 2000. Se caracteriza por insertar el culto a la naturaleza en la vida doméstica, a través de conductas respetuosas con el medio ambiente y hábitos saludables. 22. NISHIZAWA, R.; TAKAHASHI, I. Opus cit. 2009. p. 25. Traducción integra de los manuscritos, por primera vez del japonés al castellano, por parte del autor.

23. DIMMER, C. Opus cit. 2012.

24. YEH, Nei-Ching: CHEN, Yi-Ju. 'On the Everyday Life Information Behavior of LOHAS Consumers: A Perspective of Lifestyle', Journal of Education Media \& Library Sciences, 48: 4, 2011. pp. 489-510.

25. NISHIZAWA, R. 'House and Garden, Japan', GA Houses, n. 131. Tokio: Tokyo ADA Edita, mayo, 2013. p. 26,

26. ZANCAN, R. Opus cit. 2011.

27. SEJIMA, K.; FUTAGAWA, Y.; NISHIZAWA, R. GA Architect: Kazuyo Sejima, Ryue Nishizawa, 2006-2011. Tokyo ADA Edita, Tokio, 2011. p. 114. 28. NISHIZAWA, R.; TAKAHASHI, I. Opus cit. 2009. p. 25. Traducción íntegra de los manuscritos, por primera vez del japonés al castellano, por parte del autor.

29. SEJIMA, K.; FUTAGAWA, Y.; NISHIZAWA, R. Opus cit. 2011. p. 114. 30. NISHIZAWA, R.; TAKAHASHI, I. Opus cit. 2009. p. 25. Traducción íntegra de los manuscritos, por primera vez del japonés al castellano, por parte del autor.

31. "Dos habitaciones individuales: Un espacio mínimamente equipado para poder concentrarse a solas en el trabajo de escribir. Equipado sólo con un escritorio, una silla y una estantería”. NISHIZAWA, R.; TAKAHASHI, I. Opus cit., 2009. p. 25. Traducción íntegra de los manuscritos, por primera vez del japonés al castellano, por parte del autor.

32. NISHIZAWA, R.; TAKAHASHI, I. Opus cit., 2009. p. 25. Traducción íntegra de los manuscritos, por primera vez del japonés al castellano, por parte del autor.

33. NISHIZAWA, R. 'Buildings that Evoke Contemporary Values', BORASI, G.; NISHIZAWA, R.; TAYLOR, S.J. Opus cit. 2008. pp. 10-13.

34. "La fachada: Les pido que den importancia a la seguridad contra rateros, robos a manos armadas e intrusos, y tomen medidas para que no se pueda atisbar el interior del edificio." NISHIZAWA, R.; TAKAHASHI, I. Opus cit. 2009. p. 25. Traducción íntegra de los manuscritos, por primera vez del japonés al castellano, por parte del autor.
21. LOHAS is the acronym for Lifestyles of Health and Sustainability. It was first enunciated in RAY, P.H.; ANDERSON, S.R. The Cultural Creatives: How 50 Million People Are Changing the World. United States of America: Harmony Books, 2000. Its principal characteristic is the insertion of nature worship in domestic life, through healthy habits and environmentally respectful conducts.

22. NISHIZAWA, R., TAKAHASHI, I. Opus cit. 2009. p. 25. Translated by the author.

23. DIMMER, C. Opus cit. 2012.

24. YEH, Nei-Ching; CHEN, Yi-Ju. 'On the Everyday Life Information Behavior of LOHAS Consumers: A Perspective of LIfestyle', Journal of

Education Media \& Library Sciences, 48:4, 2011. pp. 489-510.

25. NISHIZAWA, R. 'House and Garden, Japan', GA Houses, n. 131. p. 26, Tokyo: Tokyo ADA Edita, May 2013.

26. ZANCAN, R. Opus cit. 2011.

27. SEJIMA, K.; FUTAGAWA, Y.; NISHIZAWA, R. GA Architect: Kazuyo Sejima, Ryue Nishizawa 2006-2011, A.D.A. Edita Tokyo, Tokyo, 2011.

p.114.

28. NISHIZAWA, R.; TAKAHASHI, I. Opus cit.2009. p. 25. Translated by the author.

29. SEJIMA, K.; FUTAGAWA, Y.; NISHIZAWA, R. Opus cit. 2011. p.114. 30. NISHIZAWA, R.; TAKAHASHI, I. Opus cit.2009. p. 25. Translated by the author

31. Ibidem. p. 25.

32. Ibidem. p. 25

33. NISHIZAWA, R. 'Buildings that Evoke Contemporary Values' in BORASI, G.; NISHIZAWA, R.; TAYLOR, S.J. Opus cit. 2008. pp. 10-13. 34. 'I ask you to give importance to security against burglars, thefts and intruders, and make sure the interior will not be seen'. NISHIZAWA, R.; TAKAHASHI, I. Opus cit. 2009. p. 25. Translated by the author.

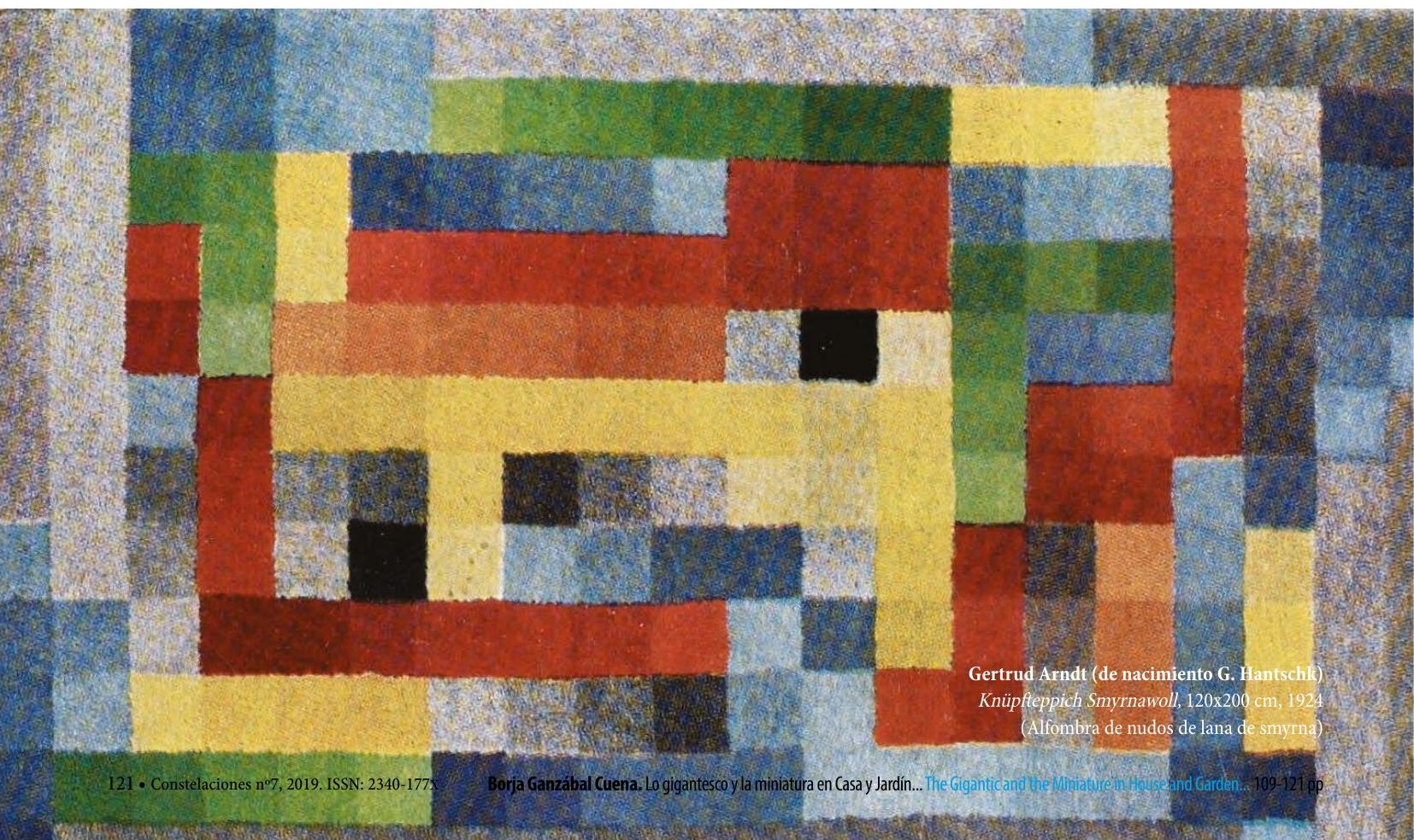

